
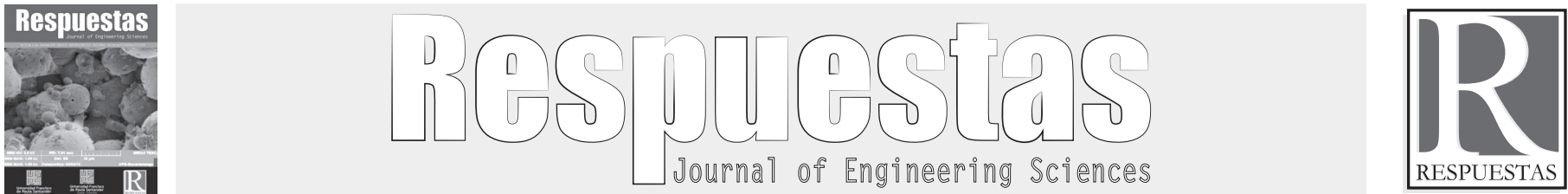

Original Article

https://doi.org/10.22463/0122820X.1736

\title{
Design turbine blade Aeolian of vertical axis using laminated tin palm material using the finite element method
}

Diseño de álabe de turbina eólica de eje vertical usando material laminado de Palma de Lata mediante el método de los elementos finitos

\begin{abstract}
Manuel del Jesús Martínez ${ }^{*}$, Juan Dayal Castro-Bermúdez², Iván Darío Ortega-Anillo³
I*Doctor en Mecánica Computacional,mjmartin@uis.edu.co, Orcid: 0000-0001-7069-6400, Universidad Industrial de Santander, Bucaramanga, Colombia, ${ }_{2}^{2}$ Ingeniero Mecánico, juan.castro3@correo.uis.edu.co, Orcid: 0000-0002-5127-4904, Universidad Industrial de Santander, Bucaramanga, Colombia,

3ngeniero Mecánico, ivandarioortegaanillo@gmail.com, Orcid:0000-0002-1750-4315, Universidad Industrial de Santander, Bucaramanga, Colombia,
\end{abstract}

How to cite: M.J. Martínez, J.D. Castro-Bermúdez and I.D. Ortega-Anillo, "Design turbine blade Aeolian of vertical axis using laminated tin palm material using the finite element method”, Respuestas, vol. 23, no. 2, pp. 43-52, 2018

Received on January 17, 2018 - Approved on June 09, 2018.

\begin{tabular}{|c|c|}
\hline & CT \\
\hline $\begin{array}{l}\text { Can Palm, } \\
\text { Design, Fault } \\
\text { Theories, Finite } \\
\text { Element Method, } \\
\text { Simulation, }\end{array}$ & $\begin{array}{l}\text { This work focuses in analyze the mechanical behavior of a vertical axis wind turbine Blade, which } \\
\text { is constituted by a natural composite material of "Palma de Lata" and binder, constituents for which its } \\
\text { mechanical properties are obtained through mechanical tests and literature references. This study was made } \\
\text { under the wind conditions of the colombian "Cañon del Chicamocha", whose aerodynamic loads (pressures) } \\
\text { were obtained in previus studies. The Design was made base on the layers layout of the composite, from } \\
\text { stress distribution analysis the critical regions to reinforce the blade were found. At last, the behavior of the } \\
\text { reinforced Blade was verified, obtaining in the "Palma de Lata" laminated a feasible alternative to be used } \\
\text { in the wind turbines design. }\end{array}$ \\
\hline
\end{tabular}

\section{RESUMEN}

Palabras clave:

Palma de Lata, Diseño, Teorías de Falla, Método de Elementos Finitos, Simulación, Álabe de Turbina
El presente trabajo se enfoca en analizar el comportamiento mecánico de un álabe de aerogenerador de eje vertical, el cual está constituido por material natural compuesto de Palma de Lata y aglomerante, constituyentes para los cuales se obtuvieron sus propiedades mecánicas por medio de ensayos mecánicos y referencias de literatura. Este estudio se realizó bajo las condiciones de viento del Cañón del Chicamocha colombiano, cuyas cargas aerodinámicas (presiones) fueron obtenidas en estudios previos. Se realizó el diseño del álabe basado en la disposición de capas del material compuesto, a partir del análisis de las distribuciones de esfuerzos se hallaron las regiones críticas para reforzar el álabe. Finalmente, se verificó el comportamiento del álabe reforzado, obteniendo en el laminado de Palma de Lata una alternativa factible para ser usada en el diseño de aerogeneradores.

\section{Introduction}

Composite materials are one of the most important research topics of recent times, this has been due to the great utility of fiberglass and carbon composites in an appreciable amount of engineering applications, in addition the study of composite materials has an inherent complexity to their structure, manufacture and anisotropy presented [1]-[3], which makes it an area of interest for research.

Ecological and sustainable ideas have significantly impacted the advancement of science, wanting to narrow the gaps that still exist between nature and

*Corresponding author.

E-mail address: mjmartin@uis.edu.co (Manuel del Jesús Martínez)

(c) $(1)$ Peer review is the responsibility of the Universidad Francisco de Paula Santander

cc) This is an article under the license CC BY-ND (http://creativecommons.org/licenses/by-nc-nd/4.0/) 
technology, thanks to the desire to reduce the impact of pollution and reduce the amount of solid waste [4],[5]. A controversial example is observed in wind turbines [6], one of their main construction materials being fiberglass composites that are potential contaminants of water, affecting marine fauna [7] and presenting problems such as reduced properties or obsolescence when recycled [8]. As shown in [9] one of the desired alternatives for the handling of synthetic compounds is to prevent the production of waste; therefore, if the use of synthetic raw material is reduced by replacing it with biodegradable materials [10], both solid waste and the contamination inherent in the manufacture of artificial compounds would be significantly reduced [11]. This project proposes as an alternative the use of tin palm (Bactris Guineensis) as a replacement for synthetic fibers for applications with low loads, so that organic materials are used for their manufacture.

The Tin Palm is found in regions of South America [12] and is used to obtain drinks with a high content of antioxidants [13] and wines, its stem has been used in reinforcements of old constructions but few studies [14], [15] and [16] have focused on the mechanical characterization of the Tin Palm, consequently, it became necessary to study the mechanical behavior of this palm and thus take the first steps to design structural elements that take advantage of this raw material.

One of the best known applications for composite materials are wind turbines, these have gained popularity worldwide because of their ability to generate "clean" energy with wind currents. However, most of the global electrical energy still has a fossil origin which worsens the current situation of climate change due to the greenhouse effect generated by these energy sources. In addition, because turbines are built with these materials, they carry with them a problem that goes against their purpose with the environment.

In Colombia by 2010 more than $25 \%$ of the energy produced in the country was of fossil origin [17], which is not bad compared to some countries that have a much higher percentage in this category, however, the goal according to scientists is to reduce carbon emissions into the air as soon as possible, which means that the target for the value shown is $0 \%$.

This work investigates the behavior of the Palma de Lata as a structural material for blades of vertical axis wind turbines. With the purpose of contributing from the academy in the sustainable development of the country and in such a way to contribute with its economic, cultural and social development.

\section{Materials and methods}

\section{Finite Element Analysis}

The Finite Element Method (FEM) [18] is a numerical technique used to solve problems with a high degree of complexity, for which it is difficult to solve analytically. The method has, therefore, great application in engineering problems [19], [20].

In this work was studied the behavior of a H-Rotor type wind turbine blade using F.E.M, with the aerodynamic profile DU06W200 was studied by [1] for the wind conditions of the Chicamocha Canyon of Colombia, the design of the blade adds an internal stiffener based on the results obtained in [21].

\section{Galerkin Method}

There are several methods to solve a finite element problem, in this work is used the Galerkin method which is commonly used by finite element software such as ANSYS. This method is based on looking for the solution by means of test functions, to the system of linear equations. $\mathbf{K U}=\mathbf{F}$ describing Hooke's law, where the term $\mathbf{U}$ is the vector of displacements, $\mathbf{F}$ the vector of equivalent forces and $\mathbf{K}$ the stiffness matrix of the material.

$$
\int_{\Omega} \boldsymbol{\varepsilon}(\mathbf{v})^{\mathrm{T}} \mathbf{D} \boldsymbol{\varepsilon}(\mathbf{u}) \mathrm{d} \Omega=\int_{\Omega} \mathbf{v}^{\mathrm{T}} \mathbf{b} \mathrm{d} \Omega+\int_{\Gamma_{\mathrm{N}}} \mathbf{v}^{\mathrm{T}} \mathbf{t} \mathrm{d} \Gamma
$$

In (1) the variational formulation is shown, in which a solution must be found. $\mathbf{u}^{\mathrm{h}} \in \mathbf{V}^{\mathrm{h}}$ what if $\forall \mathbf{v} \in \mathbf{V}^{\mathrm{h}}$ is fulfilled (1).

\section{Properties of the study material}

To define the matrix of elasticity of an anisotropic 
material it is necessary to know the 36 constants, which allow to define the law of three-dimensional Hooke, in the case of orthotropic materials due to the symmetry previously mentioned, the constants are reduced to 12 to define the elastic problem.

The tensorial form of Hooke's law of elasticity in a solid can be written as:

$$
\sigma_{i j}=C_{i j k l} \varepsilon_{k l}
$$

Where the terms, y represents the stress, deformation and stiffness tensors of the material respectively.

This law can be represented in terms of the elasticity tensor $S_{i j k l}$ like:

$$
\varepsilon_{k l}=S_{i j k l} \sigma_{i j}
$$

The Tin Palm presents a zone of high rigidity in the external bark of the stem [15] similar to what happens with Bamboo [22], therefore from this zone the sheets for the composite material were obtained, for this external bark a transverse isotropy behavior is assumed, an assumption accepted for similar composite materials such as parallel fiber Bamboo (PSB) [23], thus reducing the constants that define the elasticity tensor to $5: S_{11}, S_{12}, S_{22}, S_{66}$, y $S_{23}$ ó $S_{44}$. in (4) the matrix form of Hookès law is shown in terms of the engineering constants, as considered for this study.

$$
\left\{\begin{array}{c}
\varepsilon_{1} \\
\varepsilon_{2} \\
\varepsilon_{3} \\
\gamma_{23} \\
\gamma_{13} \\
\gamma_{12}
\end{array}\right\}=\left[\begin{array}{cccccc}
\frac{1}{E_{1}} & -\frac{v_{12}}{E_{2}} & -\frac{v_{12}}{E_{2}} & 0 & 0 & 0 \\
-\frac{v_{12}}{E_{2}} & \frac{1}{E_{2}} & -\frac{v_{23}}{E_{2}} & 0 & 0 & 0 \\
-\frac{v_{12}}{E_{2}} & -\frac{v_{23}}{E_{2}} & \frac{1}{E_{2}} & \frac{1}{G_{23}} & \frac{1}{G_{12}} & 0 \\
0 & 0 & 0 & 0 \\
0 & 0 & 0 & 0 & & 1 \\
0 & 0 & 0 & 0 & 0 & \frac{1}{G_{12}}
\end{array}\right]\left\{\begin{array}{c}
\sigma_{1} \\
\sigma_{2} \\
\sigma_{3} \\
\tau_{23} \\
\tau_{13} \\
\tau_{12}
\end{array}\right\}
$$

Besides this, the dependence of the fourth term of the main diagonal is fulfilled such that:

$$
G_{23}=\frac{E_{2}}{2 *\left(1+v_{23}\right)}
$$

\section{Composite Failure Theories}

Failure criteria in finite element software are commonly represented from the failure index, which is represented as:

$$
I_{F}=\frac{\text { Strain }}{\text { Strength }}
$$

Or its inverse:

$$
R=\frac{1}{I_{F}}=\frac{\text { Strength }}{\text { Strain }}
$$

In this case, the resistance is taken as the limit in which the breakage of the first can palm fibers occurs, as shown in [24]. In order to avoid failure, the failure rate must be greater than 1 .

\section{Maximum effort failure theory}

In this criterion is not considered any interaction between different stress components, the failure occurs when the stress in any direction exceeds the maximum value allowed by the compound in that direction. In the same way the maximum deformation evaluates when the material reaches its limit deformation in any direction so that the failure at this point will have already occurred.

The maximum three-dimensional stress criterion is the maximum value found between the following relationships [25], in the case of normal stresses:

$$
I_{F, \sigma}=\frac{ \pm \sigma_{i}}{F_{i, t / c}}
$$

Being the normal effort in direction 1, 2 o 3, y the resistance of the material in the same direction as the stress, whether it is tensile or compressive. If $\sigma_{i}$ is less than zero, the compressive strength is used.

For shear forces:

$$
I_{F, \sigma}=\frac{\left|\tau_{i j}\right|}{F_{i j}}
$$

Where is the absolute value of the shear force in directions 12, 13 o 23 and is shear resistance in the same direction. 


\section{Fault theory of Tsai-Hill}

It is a criterion formulated referring to the energy of distortion, i.e. it takes into account interplanar shear stresses. The failure criterion is described by:

$$
I_{F, T H}=\left(\frac{\sigma_{1}}{F_{1, t / c}}\right)^{2}-\frac{\sigma_{1} \sigma_{2}}{F_{1, t / c}{ }^{2}}+\left(\frac{\sigma_{2}}{F_{2, t / c}}\right)^{2}+\left(\frac{\tau_{12}}{F_{12}}\right)^{2}
$$

Where again the parameters in the denominators are the limits of the efforts in the indicated directions.

In this work it was decided not to show failure criteria such as Tsai-Wu because biaxial testing properties would be required that were not determined for Tin Palm.

\section{Modeling}

For this simulation the DU06W200 profile is used, the $3 \mathrm{D}$ model is created by importing the coordinates of the points and then extruding them, then the internal reinforcement of the blade is positioned, its location is at $20 \%$ of the length of the rope, which for this simulation is $25 \mathrm{~cm}$, i.e. the stiffener is located 5 centimeters from the nose of the blade, distance determined in previous works [21], [26], the length of the blade is 2 meters, taking as a reference that the aspect ratio (ratio between blade length and rope length) for this type of turbines should not be less than 7.5 [27].

The laminate is made in normal direction to the surface, for the internal reinforcement, sheets are placed on both sides of the base geometry that is inside, in addition, the joint between the stiffener and the walls of the blade is made in the form of " $\mathrm{T}$ " adhering through a layer of material.

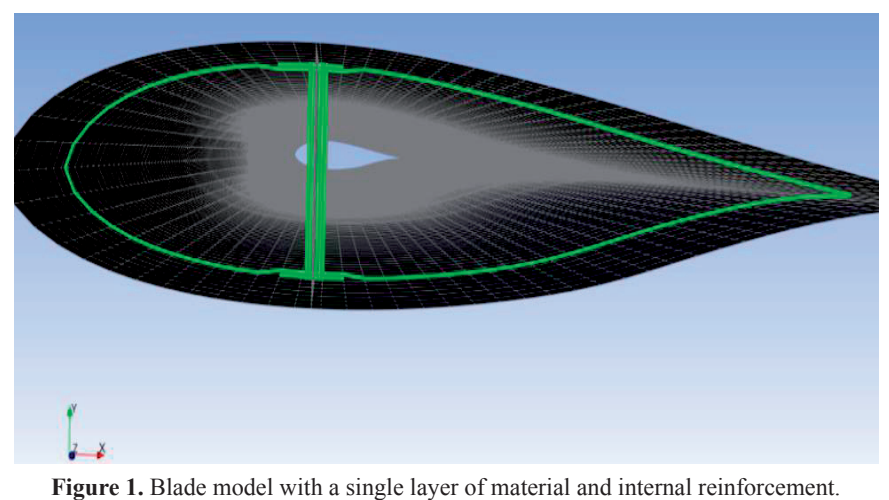

\section{Materials}

In order to simulate the blade and verify the failure criteria, it was necessary to mechanically characterize the Can Palm, using as a guide the ASTM D3039, E132-04, D1037 and D7078 standards to obtain the great majority of the engineering constants required in (5) when testing: Traction in direction 1 and 2, Poisson Coefficient and Cutter in direction 12.

Table I. Properties of the tin palm used for simulation. The (+) symbol on the right side of a property indicates that it is based on literature.

\begin{tabular}{|c|c|}
\hline Property & Magnitude \\
\hline$E_{1}$ & $13150[\mathrm{MPa}]$ \\
\hline$E_{2}$ & $832[\mathrm{MPa}]$ \\
\hline$F_{1, t}$ & $8.085[\mathrm{MPa}]$ \\
\hline$F_{2, t}$ & $3.554[\mathrm{MPa}]$ \\
\hline$G_{23^{+}}$ & $244.17[\mathrm{MPa}]$ \\
\hline$G_{12}$ & $331[\mathrm{MPa}]$ \\
\hline$\tau_{23, u^{+}}$ & $0.7496[\mathrm{MPa}]$ \\
\hline$\tau_{12, u}$ & $4.8272[\mathrm{MPa}]$ \\
\hline$v_{23}+$ & 0.7032 \\
\hline$v_{12}$ & 0.35 \\
\hline$F_{1, c^{+}}$ & $44[\mathrm{MPa}]$ \\
\hline$F_{2, c}+$ & $15.537[\mathrm{MPa}]$ \\
\hline
\end{tabular}

The remaining properties of the Palm are obtained by averaging or comparing proportions. In the first instance, the maximum compressive stress was taken from [14] for the stem of dry and complete canned palm. The was taken as the average of this property for hardwoods presented in [28] of woods, which together with was calculated by means of (5). Huang's work [23] compares the limits: y for the maximum shear force in PSB, obtaining that is $44.3 \%$ less than, for La Palma was obtained experimentally and conserving the proportion of the PSB is a approximate. Finally, in order to determine $\mathrm{F}(2 \mathrm{c})$, the comparison process is repeated using as a guide the PSB.

Polyvinyl alcohol (PVA) [29] was used as a binder, which was chosen as an adherent because it is of natural origin and soluble in water so that it can be removed with a relatively simple process, in addition to this, PVA is commonly used as for the union of wood pieces [30], the limit stress to traction and the modulus of elasticity of the work were taken from 
Chan's work [29], and the Poisson coefficient from Chen's work [31].

Table II. Pva adhesive properties
\begin{tabular}{|c|c|}
\hline Property & Magnitude \\
\hline$F_{t}$ & $0.3485[\mathrm{MPa}]$ \\
\hline $\mathrm{E}$ & $490.411[\mathrm{MPa}]$ \\
\hline$v$ & 0.4498 \\
\hline
\end{tabular}

Lamination is performed by placing a layer of PVA between two layers of Tin Palm as shown in Figure 2, the thicknesses of the Palm sheets are taken to be $1 \mathrm{~mm}$ due to the limited thickness of the Palm bark, and the thickness of the PVA layer is taken to be 0.3 millimetres.

\section{Contour and mesh conditions}

The blade is supported by 2 rectangular structural steel bars that are directly attached to the internal stiffener in order to approximate the contour conditions to which the blade would be subjected when in a turbine. However, this is a simplification as the supports must actually go from edge to wind and must have the shape of an aerodynamic profile that produces low lift when it produces little drag, so as not to hinder the operation of the turbine.

The load conditions imposed in the model are taken from [32], in this case only the pressure distribution was taken, which in [32] was determined bidimensionally around the profile, which is considered constant along the blade for this study.

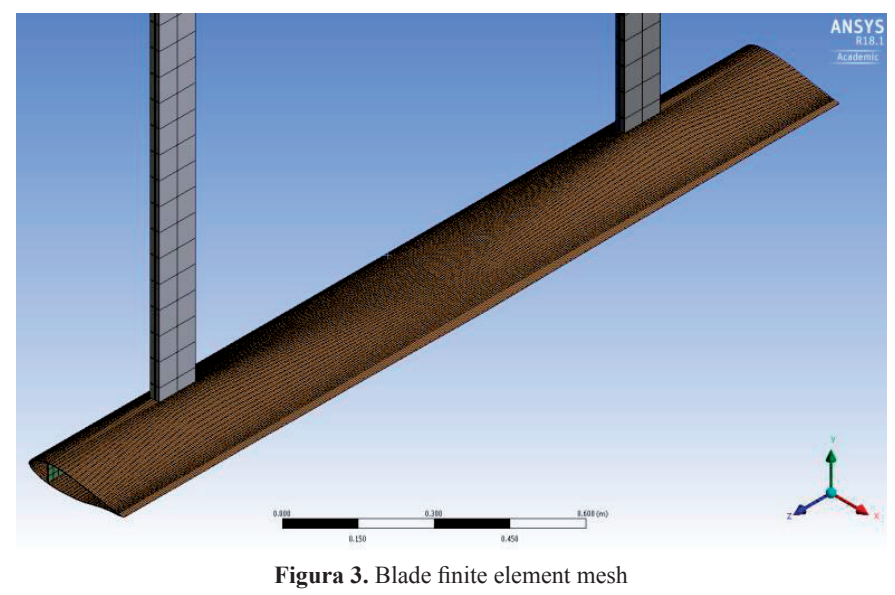

The parameterization of the number of elements and the maximum total displacement was carried out, in order to look for a sufficiently fine mesh so that the results are independent of the quantity of elements, finding that close to 8000 elements this behavior is observed, working this way the final model with 40360 elements type SHELL 181 with 6 degrees of freedom, recommended to analyze structures thin to moderate thickness.

\section{Results and discussion}

\section{Blade with a composite layer}

A first simulation was performed to visualize the behavior of the Palma-PVA compound with a single layer as shown in Figure 2, this was arranged

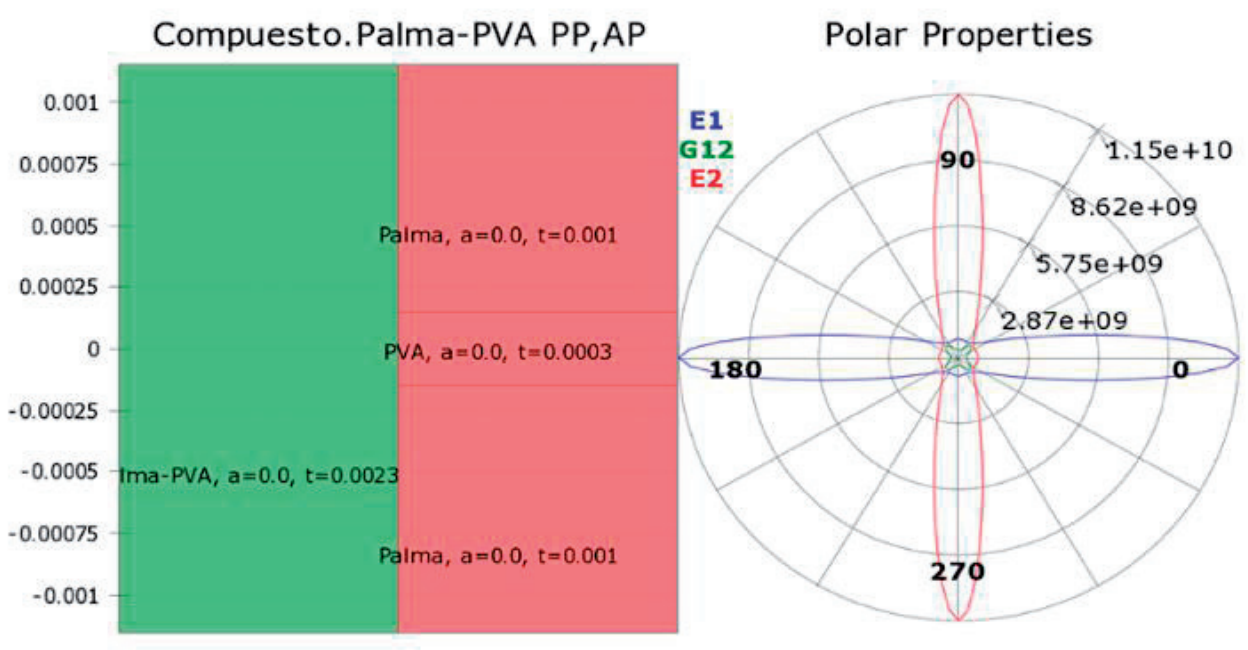

Figure 2. Stacking Order of Material Layers and their Properties 
both in the profile and in the internal stiffener, the distribution of displacements, stresses and failure criteria were visualized to identify the critical regions in the model.

Figure 4 shows the total displacements of the blade, a maximum value can be seen in the center of the area that is not subject, which is in line with expectations. It can also be seen that the zone of maximum displacement is located in the upper region of the blade where the sustentation occurs. The maximum value of total displacements is 0.075 [mm] which will not affect the structural integrity of the blade.

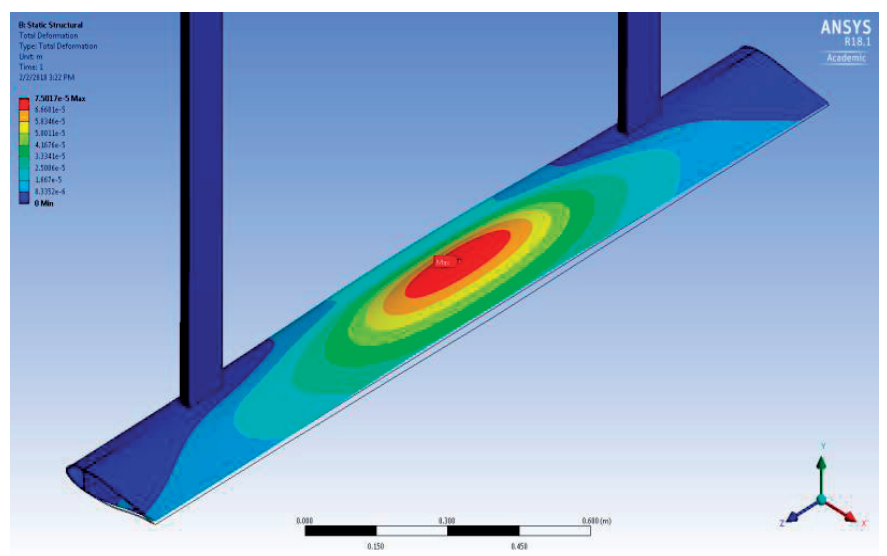

Figure 4. Total displacements of the blade

When analyzing the distribution of efforts, it is noticed that the blade has 2 critical regions: the distant exit edge to the supports and the entry edge in the region adjacent to the supports, in both failing in the direction of the matrix the Palma de Lata (direction 2), but not in the same sheet.

As can be seen in figure 5 (a), the leading edge has maximum stresses on the palm outer sheet with a value of 22.7. [MPa], that when compared to the limit value in Table 1 of $3.55[\mathrm{MPa}$ ] by means of (7) and (8) an inverse fault index value of 6.39 is obtained indicating a fault in this zone.

Now, when observing figure 5 (b) it was found that it is the inner sheet that presents the greatest efforts, with a maximum of $60.54[\mathrm{MPa}]$, resulting in an inverse failure rate of 17.55 , this region being more critical than the leading edge.

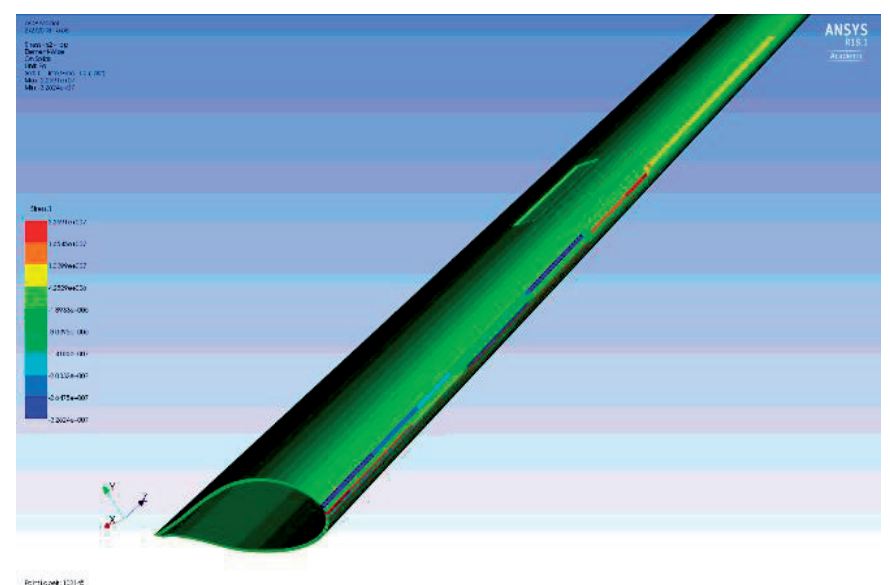

(a)

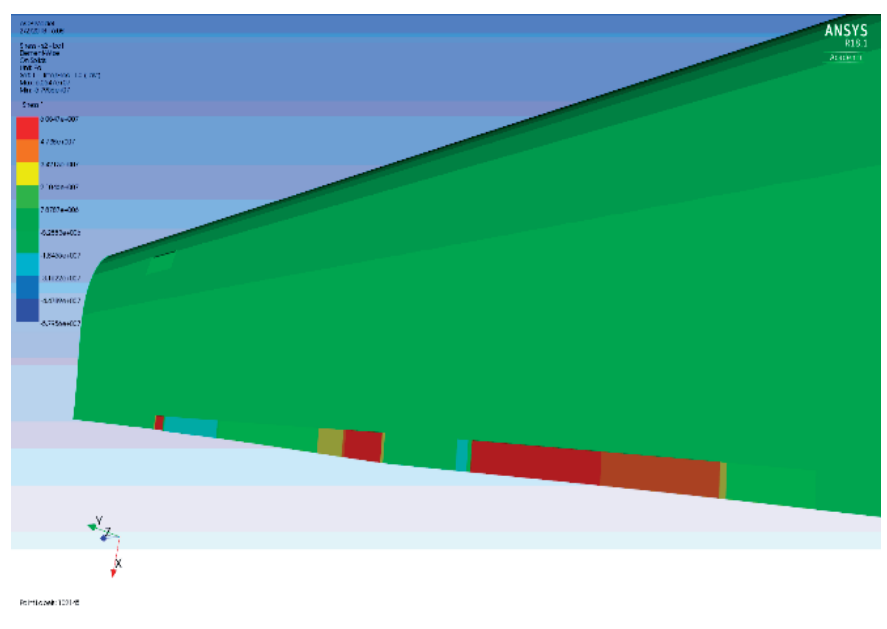

(b)

Figure 5. Stress distribution in direction 2 of: (a) Tin Palm Outer Sheet, (b) Tin Palm Inner Sheet

The trailing edge region is the one that obtains higher inverse failure index values, greater than 15 for all the fault criteria analyzed, and the fault is present in the inner sheet of Palma de Lata, this may be due to the fact that in this region the upper and lower surfaces come together creating a vertex that generates a concentration of stresses.

\section{Blade reinforced with more layers}

Because the previous blade was faulty, the blade was reinforced by adding 2 external layers of PVAPalma to stiffen the entire blade. Two more layers of PVA-Palma were added to the inlet and outlet edges in the internal region, as shown in Figure 6, to support and reduce the concentration of stresses without affecting the aerodynamic profile. 




Figure 6. Blade Reinforced Configuration

Figure 7 shows the total displacements for the reinforced blade, obtaining a maximum equal to $0.1295[\mathrm{~mm}]$ at the edge of the blade, again this value does not affect the integrity of the blade, even so it must be noted that this value is greater than that found for the blade with a single layer of laminate, this is because the reinforcements make the displacements are distributed evenly throughout the body of the blade by introducing a rotation of the point further away from the supports, unlike the local deformation shown in the figure, which is different from the local deformation shown in the figure.

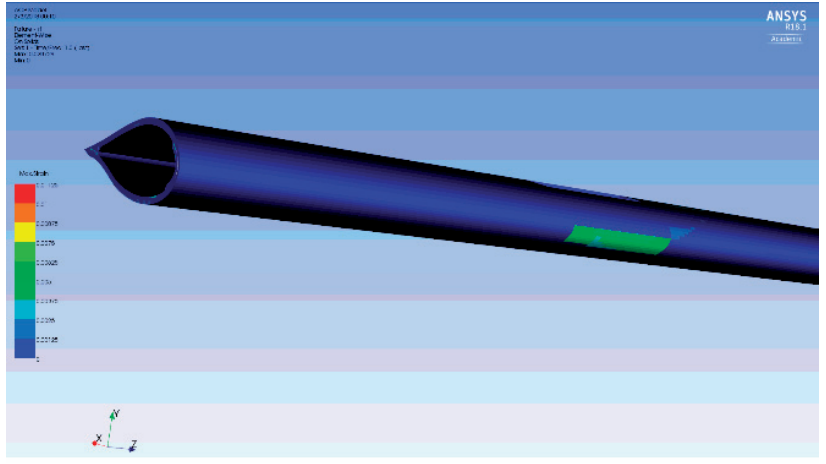

(a)

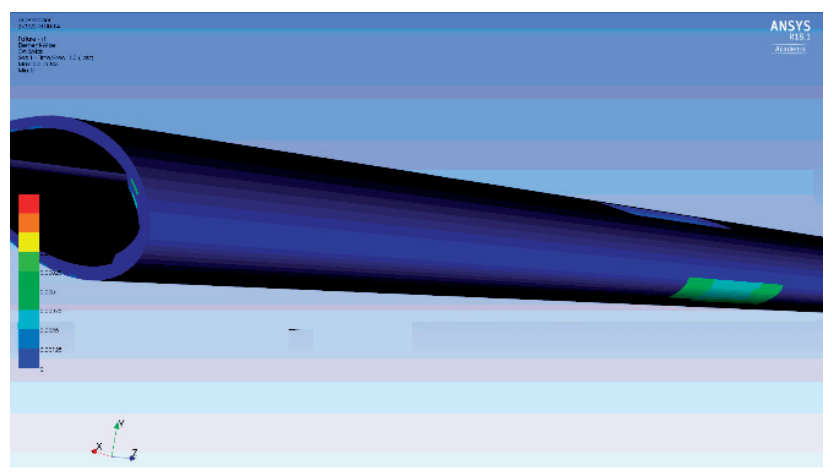

(b)

Figure 8. Failure Criteria: (a) Maximum stress and (b) Tsai-Hill

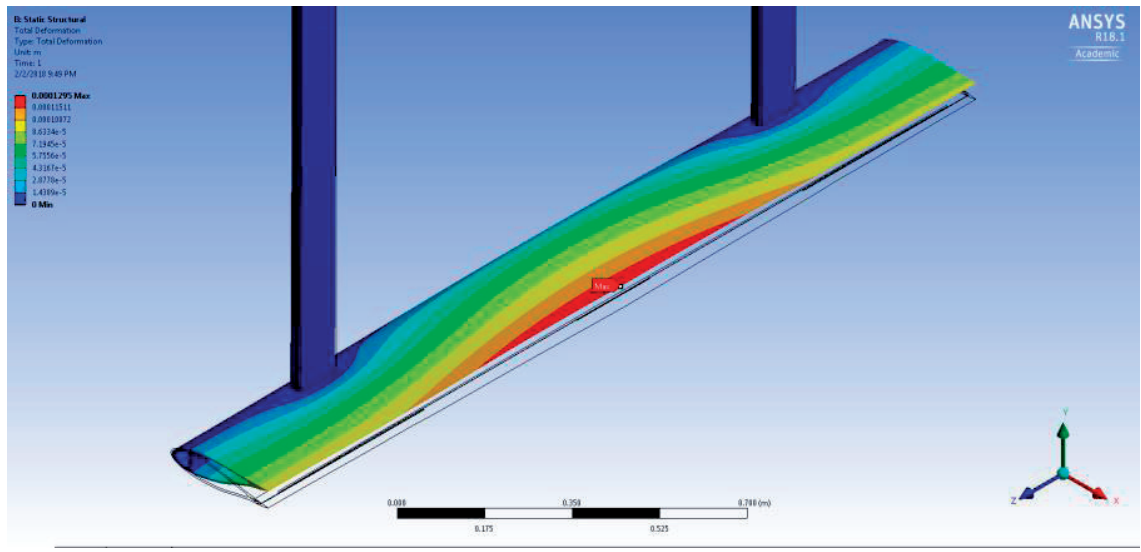

Figure 7. Total displacements of the reinforced blade

Finally, to corroborate that reinforcements also help to reduce stress and avoid material failure, the Tsai-Hill maximum stress failure criteria are shown in Figure 8 (a) and 8 (b), obtaining inverse failure index values of 0.2872 and 0.168 respectively, which indicate that there is no material failure, even so it should be noted that the entry edge zone located just in front of the supports, is still an area of interest.
A comparison with the literature shows that the work done gives similar results in terms of deformations and stresses. As shown in Wang [33], the deformation increases to a maximum in the blade as it moves away from the support, in Raciti [34] the trailing edge is observed to rise as it deforms. As far as the stresses are concerned, Liu [35] describes how the maximum stress occurs in the area where the blade 
supports are located, in the same way as the results found in this work.

\section{Conclusions}

The displacements in the composite blade of canned palm with PVA do not present critical values, with maximums of only $0.075[\mathrm{~mm}]$ for the single-layer blade and $0.1295[\mathrm{~mm}]$ for the reinforced blade.

The reinforcement layers in the blade help to substantially reduce the stresses obtained, leading to a substantial reduction in failure, showing that the inverse failure rate for the maximum stress theory can be reduced more than 60 times, from 17.55 obtained for a single layer to 0.2872 with reinforcements. Because for the 3 tested failure theories the inverse failure rates are significantly lower than 1 , it can be said that the reinforced blade does not fail with the loads that were imposed.

Finally, it can be said that the tin palm and PVA composite material provides a viable alternative, which can be used as a replacement for synthetic compounds in both wind turbines and low load structures.

\section{References}

[1] L. García, J. Jaramillo and J. Chacón, "Análisis aerodinámico del perfil de los álabes de una turbina eólica de eje vertical mediante simulación en 2d usando cfd," Universidad Industrial de Santander, 2014.

[2] T. S. Sene, L. V. da Silva, S. C. Amico, D. Becker, A. M. Ramirez, and L. A. F. Coelho, "Glass fiber hybrid composites molded by RTM using a dispersion of carbon nanotubes/ clay in epoxy," Material Resistance, vol. 16, no. 5, pp. 1128-1133, 2013.

[3] G. Suresh, L. S. Jayakumari, G. Suresh, and L. S. Jayakumari, "Evaluating the mechanical properties of E-Glass fiber/carbon fiber reinforced interpenetrating polymer networks," Polímeros, vol. 25, no. 1, pp. 49-57, 2015.

[4] Á. O. Díaz-Rey, J. E. González-Gil, O. A. González-Estrada, Á. Díaz Rey, J. González
Gil, and O. A. González-Estrada, “Análisis de un generador de HHO de celda seca para su aplicación en motores de combustión interna," Rev. UIS Ing., vol. 17, no. 1, pp. 143-154, 2018.

[5] Y. J. Rueda Ordóñez, K. K. Tannous, Y. RuedaOrdóñez, and K. K. Tannous, “Análisis cinético de la descomposición térmica de Biomasa aplicando un esquema de reacciones paralelas independientes," Rev. UIS Ing., vol. 16, no. 2, pp. 119-128, 2017.

[6] K. Molina, D. Ortega, M. Martínez, W. Pinto Hernández, and O. A. GonzálezEstrada, "Modelado de la interacción fluido estructura (FSI) para el diseño de una turbina eólica HAWT," Rev. UIS Ing., vol. 17, no. 2, pp. 269-282, 2018.

[7] E. Galimany, M. Ramón, and M. Delgado, "First evidence of fiberglass ingestion by a marine invertebrate (Mytilus galloprovincialis L.) in a N.W. Mediterranean estuary," Mar. Pollut. Bull., vol. 58, no. 9, pp. 1334-1338, 2009.

[8] J. Beauson and P. Brøndsted, "Wind Turbine Blades: An End of Life Perspective," in MARE-WINT, Cham: Springer International Publishing, pp. 421-432, 2016.

[9] WIND EUROPE, "Discussion paper on managin composite blade waste," 2017. [Online]. Available: https://windeurope. org/wp-content/uploads/files/policy/topics/ sustainability/Discussion-paper-on-bladewaste-treatment-20170418.pdf.

[10] L. Mishnaevsky, P. Freere, R. Sinha, P. Acharya, R. Shrestha, and P. Manandhar, "Small wind turbines with timber blades for developing countries: Materials choice, development, installation and experiences," Renew. Energy, vol. 36, no. 8, pp. 2128-2138, 2011.

[11] M. Ho et al., "Critical factors on manufacturing processes of natural fibre composites," Compos. Part B, vol. 8, no. 8, pp. 3549-3562, 2012. 
[12] M. J. Plotkin, L. Famolare, Conservation International., and Asociación Nacional para la Conservación de la Naturaleza., Sustainable harvest and marketing of rain forest products. Island Press, 1992.

[13] C. Osorio, J. G. Carriazo, and O. Almanza, "Antioxidant activity of corozo (Bactris guineensis) fruit by electron paramagnetic resonance (EPR) spectroscopy," Eur. Food Res. Technol., vol. 233, no. 1, pp. 103-108, Jul. 2011.

[14] I. Gil, R. Prada, and A. Rey, “Análisis y caracterización de las propiedades físicas y mecánicas de la palma de lata," Universidad Industrial de Santander, 2008.

[15] D. Chavez, F. García, and A. Pertuz, "Estudio del comportamiento dinámico de un material compuesto laminado elaborado a partir de la corteza de la palma de lata," Universidad Industrial de Santander, 2016.

[16] D. Castro and I. Ortega, "Caracterización ortotrópica de las propiedades mecánicas de la palma de lata para su uso como reemplazo de fibras sintéticas en turbinas eólicas," in COIES2017 - Conferencia Internacional de Energía Sostenible \& Workshop Materiales para Nuevas Tecnologías de Energía, 2017.

[17] UNIDAD DE PLANEACIÓN MINERO ENERGÉTICA, "INFORME SECTORIAL SOBRE LA EVOLUCIÓN DE LA DISTRIBUCIÓN Y COMERCIALIZACIÓN DEENERGÍAELÉCTRICAENCOLOMBIA," 2011. [Online]. Available: http://www.upme. gov.co/Docs/Asocodis_2010.pdf.

[18] O. C. Zienkiewicz, El método de los elementos finitos. Reverté, 1982.

[19] A. Ayestarán, C. Graciano, and O. A. GonzálezEstrada, "Resistencia de vigas esbeltas de acero inoxidable bajo cargas concentradas mediante elementos finitos," Rev. UIS Ing., vol. 16, no. 2, pp. 61-70, Sep. 2017.
[20] J. Martínez, E. Casanova, C. Graciano, and O. A. González-Estrada, "Sensitivity analysis of a member under compression via Monte Carlo method," Rev. UIS Ing., vol. 17, no. 2, pp. 179-184, 2018.

[21] D. Castro, I. Ortega, and R. Güiza, "Reducción de los esfuerzos y las deformaciones de un álabe de turbina eólica de eje vertical por medio de refuerzos estructurales internos," in CCMN2017 - XI Congreso Colombiano de Métodos Numéricos, 2017, p. 9.

[22] A. Zhou, D. Huang, H. Li, and Y. Su, "Hybrid approach to determine the mechanical parameters of fibers and matrixes of bamboo," Constr. Build. Mater, vol. 35, pp. 191-196, Oct. 2012.

[23] D. Huang, Y. Bian, A. Zhou, and B. Sheng, "Experimental study on stress-strain relationships and failure mechanisms of parallel strand bamboo made from phyllostachys," Constr. Build. Mater, vol. 77, pp. 130-138, 2015.

[24] D. Chavez, F. Garcia, and A. Pertuz, Estudio del comportamiento dinámico de un material compuesto laminado elaborado a partir de la corteza de la pala de lata. Bucaramanga, 2016.

[25] E. J. Barbero, Finite Element Analysis of Composite Materials Using ANSYS, 2nd ed. Boca Ratón, Florida, U.S.A.: CRC Press, 2013.

[26] D. Castro, I. Ortega, and M. Martinez, “Análisis estructural de un álabe de aerogenerador de eje vertical constituido por material natural compuesto," in CIBIM 2017-XIII Congreso Iberoamericano de Ingeniería Mecánica, pp. 7, 2017.

[27] M. Islam, A. Fartaj, and R. Carriveau, "Analysis of the Design Parameters related to a Fixed-pitch Straight-Bladed Vertical Axis Wind Turbine," Wind Eng., vol. 32, no. 5, pp. 491-507, 2008.

[28] D. W. Green, J. E. Winandy, and D. E. 
Kretschmann, Mechanical properties of wood, vol. 113. 1999.

[29] K. S. Chan, H. B. Senin, I. Naimah, M. Rusop, and T. Soga, "STRUCTURAL AND MECHANICAL PROPERTIES OF POLYVINYL ALCOHOL (PVA) THIN FILM," in AIP Conference Proceedings, vol. 1136, no. 1, pp. 366-369, 2009.

[30] S. Bueno, L. Rodríguez, and R. Cruz, "Propuesta de elemento constructivo base laminado de guadua," Universidad Industrial de Santander, 2005.

[31] F. Chen, D.-J. Kang, and J.-H. Park, "New measurement method of Poisson's ratio of PVA hydrogels using an optical flow analysis for a digital imaging system," Meas. Sci. Technol., vol. 24, no. 5, p. 055602, 2013.

[32] J. E. Ibarra-Jaramillo, L. F. Rodríguez-García, and J. L. Velazco-Chacón, "MODELADO NUMÉRICO DEL PERFIL DE LOS ÁLABES DE UNA VAWT”, pp. 9, 2015.

[33] L. Wang, A. Kolios, T. Nishino, P. L. Delafin, and T. Bird, "Structural optimisation of vertical-axis wind turbine composite blades based on finite element analysis and genetic algorithm," Compos. Struct., vol. 153, no. January 2015, pp. 123-138, 2016.

[34] M. Raciti Castelli, A. Dal Monte, M. Quaresimin, and E. Benini, "Numerical evaluation of aerodynamic and inertial contributions to Darrieus wind turbine blade deformation," Renew. Energy, vol. 51, pp. 101-112, 2013.

[35] W. Liu and Q. Xiao, "Investigation on Darrieus type straight blade vertical axis wind turbine with flexible blade," Ocean Eng., vol. 110, pp. 339-356, 2015. 